\title{
A personagem teatral e o pícaro espanhol em Dois perdidos numa noite suja, de Plínio Marcos
}

\author{
Theatrical character and the Spanish picaro in Dois perdidos numa noite suja \\ by Plínio Marcos
}

Sergio Manoel Rodrigues

Faculdade Don Domênico - São Paulo - Brasil

\author{
$\diamond$
}

\begin{abstract}
Resumo: Este artigo tem como objetivo apresentar as personagens Tonho e Paco da peça Dois perdidos numa noite suja (1966), do dramaturgo Plínio Marcos, estabelecendo uma comparação das mesmas com a figura do pícaro espanhol, cujos caracteres muito se aproximam aos dos seres plinianos. Desse modo, propõe-se, inicialmente, a abordagem das principais características da personagem teatral, a fim de se verificar os elementos que constituem o ser fictício na dramaturgia e, assim, analisar os perfis e as relações existentes entre as personagens da peça em questão. Evidenciando, portanto, a marginalidade social e suas consequências (agressões, roubo, assassinato) como as principais temáticas exploradas por Plínio e pela picaresca espanhola.
\end{abstract}

Palavras-chave: Plínio Marcos; Dramaturgia; Personagem; Pícaro; Marginalidade

\begin{abstract}
This article aims to present the characters Tonho and Paco of the play Dois perdidos numa noite suja (1966) by playwright Plínio Marcos, thus establishing a comparison with the figure of the Spanish picaro whose characters very closely mirror those of the plinianos beings. In this way, it is proposed, initially, the approach of the main characteristics of the theatrical character, in order to verify the elements that constitute the fictitious being in the dramaturgy and, thus, to analyze the profiles and the relationships existing between the characters of the play in question. Showing, therefore, the social marginality and its consequences (assault, theft, murder) as the main themes explored by Plínio and by Spanish picaresca.
\end{abstract}

Keywords: Plínio Marcos; Dramaturgy; Character; Picaro; Marginality

Baseado no conto $O$ terror de Roma, do escritor italiano Alberto Moravia, Dois perdidos numa noite suja seria, a princípio, um "teleteatro" para o programa TV de Vanguarda, da extinta TV Tupi, onde Plínio Marcos trabalhava como roteirista e ator. Intitulada de $O$ terror, essa adaptação do texto de Moravia foi recusada pela direção do programa, que alegou morbidez da trama e crise financeira na produção da TV de Vanguarda. Segundo Freire (2008), Plínio ficou muito impressionado com a trajetória dos dois meliantes do conto de Alberto Moravia e, mesmo depois da recusa de seu roteiro para a $\mathrm{TV}$, o dramaturgo decidiu dar continuidade a seu projeto de escritura, transformando sua adaptação televisiva em uma peça de teatro.

No entanto, o receio de ser censurado pela ditadura militar da época, como aconteceu com suas obras anteriores, levou Plínio Marcos a alterar o título de sua peça de $O$ terror para Dois perdidos numa noite suja, para que ela não fosse relacionada ao clima de terrorismo que se manifestava no Brasil, por conta dos atentados e das guerrilhas entre grupos armados de esquerda e as organizações militares brasileiras (FREIRE, 2008).

Dois perdidos foi encenada pela primeira vez em um bar, no Centro de São Paulo, em 16 de dezembro de 1966, alcançando um inesperado sucesso de crítica. De acordo com Vieira (1994, p. 73), o crítico teatral "João Apolinário sustentou, entusiasticamente, que a peça é uma pequena obra-prima da dramaturgia brasileira [...]”. O crítico (apud VIEIRA, 1994) ainda elogiou o dramaturgo pela construção das personagens Tonho e Paco, que beiram à margem da sociedade, e pela forma como se dá a tensa relação entre elas no decorrer da trama.

Outro especialista da área, Alberto D’Aversa, sobre a estreia dessa peça, declarou que esta era "[...] sem dúvida a peça mais inquietante e viva destes últimos e anêmicos anos de teatro brasileiro" (apud MENDES, 2009, p. 136). 
Portanto, esse foi o texto teatral que projetou a carreira de Plínio Marcos como dramaturgo. Liberada pelos censores da época, a peça iniciou temporada em vários teatros, a começar pelo Teatro de Arena, em São Paulo, e, em seguida, Plínio autorizou a montagem de Dois perdidos no Rio de Janeiro, o que consolidou de vez sua dramaturgia.

A que se refere ao universo dramatúrgico de Plínio Marcos, observa-se que este é habitado por seres marginalizados, que podem ser vistos como indivíduos que "[...] tiveram suas vozes muitas vezes silenciadas por um poder violento e excludente, o qual quase sempre funcionou no sentido de garantir os interesses das classes dominantes" (MARTIN, 2008, p. 13-14). Por sua vez, o teatro pliniano mostra aos espectadores os dramas de figuras marginais como o foco de atenção: Plínio Marcos deu tratamento mais realista, no teatro brasileiro, a esses seres ficcionais, expondo em suas peças a condição dos menos favorecidos. Nesse sentido, quando se fala em realismo na literatura e no teatro, nota-se que tal termo, muitas vezes, "[...] adquire o sentido de confrontação com uma realidade desagradável [...]" (PEACOCK, 1968, p. 29), o que acontece nas peças plinianas, nas quais os seres ficcionais se deparam com situações que os desestabilizam moral e socialmente, causando-os uma imersão na marginalidade.

Segundo Martin (2008), a marginalização do indivíduo caracteriza-se pela desumanização deste; haja vista que a condição marginalizada condiciona o sujeito a enfrentar a realidade de modo que aja conforme seu instinto de sobrevivência, com a prática de ações ilícitas, como o roubo, por exemplo, contra a sociedade. Essa ausência de cidadania, acrescentam Enedino e Sousa (2014), é uma demonstração de força desses indivíduos e faz com que eles fiquem cada vez mais à margem social.

No caso de Dois perdidos numa noite suja, Mendes $(2009$, p. 130) observa que tal peça não trata "[de] dois marginais. Dois marginalizados, o que é muito diferente. Dois homens que não haviam merecido sequer um olhar. De ninguém. Nem do teatro". Quando essa peça foi encenada pela primeira vez, expor as dificuldades enfrentadas pelas minorias era - e continua sendo necessário para se mostrarem os problemas sociais enfrentados por um país que, dos anos 50 aos 70, sofreu os mandos e desmandos de governos militaristas.

Ainda de acordo com Mendes (2009), essas personagens marginalizadas incomodam o público não porque suas falas são carregadas de palavras de baixo nível, mas porque falam o que sentem e o que pensam a respeito de suas necessidades pessoais. Deve-se notar que, nas peças de Plínio Marcos, além da presença de personagens marginalizadas, tais como prostitutas, homossexuais ou indivíduos em péssimas condições de vida, a linguagem marginal e a violência exposta em cena "agridem" o público mais conservador e fazem que esse dramaturgo se diferencie dos demais autores teatrais brasileiros.

\section{A personagem teatral}

Para uma melhor compreensão acerca dos seres ficcionais de Plínio Marcos, faz-se necessária, antes, a exposição de alguns aspectos relevantes para a caracterização da personagem teatral, com o intuito de se aprofundar a análise que este artigo propõe em relação à dramaturgia pliniana.

Cabe frisar que, nos textos ficcionais, a personagem é elemento importante para o desenvolvimento da ação. Para Candido e Prado (2009), a "camada imaginária" da ficção se adensa por meio da personagem. Já Ceia (2010) afirma que o ser de ficção caracteriza-se como um produto atuante numa realidade criada por seu autor. Desse modo, a personagem adquire características próprias, e o públicoleitor reconhece seu caráter, chegando até a se identificar com ela. Nota-se que, muitas vezes, esse reconhecimento se dá por conta de a personagem desenvolver postura comum à dos homens e, no teatro, também pelo fato de criar e incorporar um ser ficcional, por meio da técnica de interpretação.

A palavra personagem - do grego prosopon $(=$ rosto) e do latim persona (= máscara) - remete às encenações teatrais da antiga Grécia, nas quais os atores utilizavam máscaras. Segundo Pavis (2011), no teatro grego, a máscara serviu como instrumento para a identificação da personagem, isto é, esta era a própria máscara, e o ator era "executante" de seu papel. Nessas antigas encenações, o ator não encarnava moral e psicologicamente sua personagem, mas, mesmo assim, pode-se dizer que, desde a origem do teatro, o que garante a existência da personagem teatral é a "presença viva e carnal" do ator.

De acordo com Moisés (2012), em uma peça teatral, a personagem é caracterizada como uma "individualidade autônoma". Diferentemente do que acontece no conto tradicional ou no romance, por exemplo, em que há a presença do narrador que anuncia as ações do ser ficcional; no texto teatral, a personagem não necessita de um foco narrativo que conduz suas falas e seus atos, quer dizer, ela tem voz própria e ela mesma executa suas ações. Nesse sentido, pode-se dizer que, no texto para encenação, o narrador dissipa-se em vários "eus" que falam e agem de acordo com suas vontades.

Sobre a fala e a ação da personagem teatral, Peacock (1968, p.212) esclarece que "[essa] ligação íntima entre dois modos naturais de expressão, reconhecida em manuais de interpretação teatral desde os tempos elizabetanos, é a base do drama, o qual [...] representa [personagens] em uma relação de crise entre elas". Como na vida, em que 
toda fala acompanha um mínimo de expressão gestual e de sentimentos, uma peça teatral caracteriza-se por conter seres que agem e se relacionam a partir da exposição de suas falas.

Assim, ao serem postos em cena, as falas (mesmo que proferidas de forma uníssona, como no caso do coro das antigas tragédias) e os atos das personagens, adquirem concretude cênica por serem mediados pelo diálogo, sendo este considerado uma das características elementares à essência da personagem teatral.

O diálogo - do grego dialógos (= conversa) - confere a existência do ser ficcional e do mundo habitado por este. Segundo Moisés (1974), o diálogo é o "intercâmbio verbal" entre as personagens de uma narrativa teatral e, desde sempre, estabelece as relações entre as personagens dessa narrativa. "[O] teatro é antes de tudo diálogo, ou seja, [...] nele a palavra [é] partilhada entre vários emissores. Essas palavras em ação assumidas pelas personagens constituem o essencial da ficção" (RYNGAERT, 1996, p. 12). Dessa forma, pode-se dizer que o conflito das peças teatrais é gerado continuamente na perspectiva do diálogo entre seres fictícios e, na concepção de Pavis (2011), o diálogo no teatro funciona como "troca" de pontos de vista entre as personagens.

Desse modo, nota-se que o teatro é uma forma de arte que utiliza, sistematicamente, o diálogo. Essa afirmação leva à seguinte questão: e outras narrativas, como o romance, a novela e o conto, não utilizam também o diálogo em suas tramas? Sim, utilizam; contudo os textos dramáticos têm como finalidade a encenação, enquanto que, em outros gêneros literários,

[o] diálogo literário basta-se e cumpre-se como fim em si próprio, na medida em que remete para a personagem que o enuncia, por sua vez existente como ser fictício cuja evidência se vai montando na linha do discurso, pela adesão do leitor ao espaço imaginário textual que the é oferecido. [...]

Ao contrário, o diálogo dramático atinge sua inteireza quando o ator o projeta para outros atores no jogo cênico sobre o tablado, ou quando o enuncia em monólogos ou peças de uma só personagem. [...] Por outro lado, o diálogo teatral difere do diálogo literário em razão de se destinar a ser enunciado em voz alta e implicar a presença de um corpo e de uma voz. Espécie de roteiro, script neutro, ganha vida sobre o palco, graças ao ator e sua circunstância: [...] o diálogo teatral é uma expectativa que se cumpre em abandonar-se como texto (impresso) e em se tornar ato (MOISÉS, 2012, p. 644-645).

No decorrer da peça teatral, o diálogo implica as ações da personagem e sua interação com o outro, permitindo que a consciência moral ou psicológica e as ideias do ser ficcional sejam reveladas a partir das relações que ele estabelece com os demais à sua volta.

Além dos diálogos, segundo Candido e Prado (2009), há três formas que também caracterizam o perfil da personagem no teatro: o que ela diz sobre si, as ações que desenvolve durante o enredo e o que os outros dizem dela. Essa proposta de caracterização da personagem teatral defendida pelos teóricos (2009) encontra-se, por exemplo, em Dois perdidos numa noite suja, peça na qual Plínio Marcos coloca em cena duas personagens que ganham a vida fazendo "biscate" como carregadores de um mercado. Afastados cada vez mais das convenções sociais, pois não têm uma ocupação mais rentável e são obrigados a levar uma vida criminosa, Tonho e Paco têm seus caracteres e suas vontades revelados a partir das atitudes que assumem e das relações que estabelecem entre si durante a trama.

Ainda sobre a formação da identidade do ser ficcional, interessante é a observação de Ryngaert (1996, p. 132): “[...] uma personagem não se constrói apenas a partir de seu nome, mas não podemos ignorar o modo como os autores as nomeiam". Na perspectiva do teórico (1996), os nomes dados às personagens podem revelar alguns traços de seu caráter. Reportando-se à dramaturgia de Plínio Marcos, percebe-se que, de modo geral, a maioria de suas personagens não possui nomes próprios e sim apelidos: na obra pliniana, essa ausência de identificação social podem revelar a marginalidade dos seres ficcionais, nos quais

[...] o apagamento social, a identificação informal [...] pelo apelido, exclui toda e qualquer chance [destes pertencerem] a uma classe social distinta. [Eles são] a concretização de um coletivo que vive no anonimato, pois excluir o sobrenome do indivíduo é o mesmo que dissipá-lo de sua própria essência, é colocá-lo de forma indiferente e desconsiderar a sua individualidade (ENEDINO e SOUSA, 2014, p. 375).

Sem nome nem sobrenome, as personagens de Plínio se veem impossibilitadas de ser "alguém" no contexto social ou de adquirirem bens comuns, tais como ocupação digna, família, amigos, conduta moral. Exemplificando: em Dois perdidos numa noite suja, as alcunhas dadas aos protagonistas (Tonho e Paco) são vistas como denominações que contribuem para a perda da identidade cidadã ou profissional e, por conseguinte, as características atribuídas aos seres ficcionais plinianos anulam nestes a obtenção dos valores da sociedade.

\section{O pícaro espanhol}

Considerando o tratamento dado pela literatura aos menos favorecidos socialmente, Geremek (1995) 
informa que, já no século XV, havia interesse por essas personagens. No entanto, a visão que se tinha dos miseráveis em textos da época era "impiedosamente sarcástica", sendo satirizados seus desvios de conduta e seus golpes de mendicância e charlatanismo. Em comparação ao tratamento conferido por Plínio Marcos aos marginalizados, nota-se que este inova, ao dar voz própria a essas personagens, sem caricaturá-las nem tipificá-las, e colocando-as em evidência na dramaturgia brasileira a partir das décadas de 1950 e 1960.

Embora, na Europa, sobretudo em países como Alemanha, França, Itália e Inglaterra, os textos literários que retratavam a vida de vigaristas, mendigos e vagabundos fossem considerados obras medíocres e sem riqueza artística, na Espanha, o destino desses seres ficcionais foi posto em destaque e incorporado à grande literatura, constituindo-se, assim, em um "novo gênero literário", entre 1552 e 1646, denominado romance picaresco. Dentre as diversas definições, pode-se tomar esse gênero literário como

[...] a marcação autobiográfica de uma vida vulgar, sem direcionamento definido, cuja preocupação é sobreviver de qualquer maneira no meio de um mundo pouco estimável. Não há um plano rigoroso: a unidade está dada pela presença constante do protagonista. Este não chega a ser, nas obras iniciais, um delinquente profissional. Vale-se de enganos e trapaças e tem como armas a resignação e a astúcia. O pícaro é de origem desonrosa; fica sozinho, aprende, é criado de muitos amos, torna-se pessimista e ressentido, e seu relato se carrega de sátira social (GONZÁLEZ, 1994, p. 221).

Apesar de seus antecedentes estarem na literatura medieval e na renascentista, a presença do pícaro como protagonista e sua vida contada em primeira pessoa são marcas das narrativas picarescas espanholas. O pícaro era definido em 1726, conforme o Dicionário da Academia da Espanha (apud GEREMEK, 1995, p.213), como "[...] baixo, criminoso, enganador, privado de honra e vergonha $[\ldots]$ ". Tal verbete da época reflete postura severa, ao relacionar diretamente a vida miserável desse indivíduo à criminalidade. No entanto, defende Candido (2004, p. 19-20): “[...] o choque áspero com a realidade leva [o pícaro] à mentira, à dissimulação, ao roubo e [...] a brutalidade da vida é que aos poucos o vai tornando esperto e sem escrúpulos, quase como defesa [...]", isto é, são as dificuldades vividas e a impossibilidade de mudanças que transformam o pícaro em um meliante.

Visto como um anti-herói, o pícaro tem sua imagem associada à do "vagabundo solitário", e sua existência é narrada desde suas origens, passando-se por uma série de aventuras até um final nada feliz. Habitando um mundo conturbado, centrado no caos das grandes cidades, a personagem pícara vive sem profissão ou ocupação definida, vendo-se obrigada a se envolver em trapaças e a se valer de meios ilícitos para sobreviver. Por isso, como afirma Geremek (1995), a figura do pícaro pode ser definida por sua marginalização social, que se dá não apenas por sua posição inferior na camada hierárquica da sociedade, mas principalmente por suas atitudes, as quais $\mathrm{o}$ afastam ainda mais das convenções sociais.

Desse modo, a literatura espanhola, mais precisamente o romance picaresco, introduz e perpetua a figura do pícaro na literatura mundial. No Brasil, esse anti-herói será representado pelo malandro, cujo “[...] comportamento, pautado pelas idas e vindas entre os polos da ordem e da desordem sociais, [...] resumiria a regra de vida de um setor intermediário da sociedade" (MARTIN, 2008, p.36). Grosso modo, a figura do malandro, constantemente retratada na literatura e na música popular, representa no imaginário cultural brasileiro a transgressão social, a contravenção e a resistência contra a ordem institucionalizada.

Numa aproximação entre o pícaro espanhol e as personagens marginais de Plínio Marcos, notam-se algumas convergências: "[...] a luta pela sobrevivência, a solidão [...], o desemprego, [...] o individualismo [...], a exposição dos preconceitos sociais, a busca pelo 'caminho fácil' do crime, o desânimo, a crueldade, a violência" (PARANHOS, 2009, p. 08). Verifica-se que as personagens plinianas, igualmente às pícaras, são vítimas da exclusão social, habitam um ambiente sórdido - apenas o que restou a elas - e, por isso, se restringem a atitudes agressivas em suas pelejas cotidianas.

Em Dois perdidos numa noite suja, por exemplo, os traços de Tonho e Paco podem ser comparados aos do pícaro espanhol. A começar pela condição de subempregados dessas duas personagens, que, tal qual o pícaro, vivem de uma ocupação irregular. Nessa comparação, pode-se dizer ainda que Tonho e Paco assumem um estado que beira à ociosidade, como se observa no seguinte fragmento: "Terceiro quadro: Tonho está deitado, Paco vai entrando. Senta-se na cama, fica olhando fixo para Tonho" (MARCOS, 2003, p. 83). Segundo González (1994), na literatura picaresca o ócio funciona como ausência do trabalho produtivo, e, assim como o pícaro clássico, as personagens plinianas buscam o que simboliza as classes superiores, como o ócio, além de bens materiais e do poder.

Por outro lado, Geremek (1995) informa que a ociosidade do pícaro é um meio de este adentrar em uma "vida antissocial", em que a vagabundagem se torna um comportamento típico desse indivíduo. No excerto de Dois perdidos, transcrito no parágrafo anterior, já passada metade do primeiro ato, ainda se percebe a falta de qualquer iniciativa das personagens. Embora trabalhem 
como carregadores no mercado (atividade esta que causa extremo cansaço físico e exige descanso ao fim do dia), as ações "estar deitado" e "olhar fixamente" revelam certa ociosidade desses seres ficcionais, que permanecem em estado de estagnação diante das dificuldades que enfrentam, como a de encontrar um bom emprego, e a falta de expectativas, justificada na seguinte fala de Paco: "Bela merda. Estudar, pra carregar caixa" (MARCOS, 2003, p. 74). Ao mesmo tempo, a acomodação desses seres ficcionais os afasta de qualquer convívio em sociedade, uma vez que ambos se isolam em seu quarto, pouco trabalham nem levam vida social ativa.

\section{Duas personagens numa noite suja}

Em suas primeiras falas, a personagem Tonho declara ser estudado e diz ter saído do interior a fim de melhores oportunidades: "Só preciso é ganhar uma grana pra me ajeitar um pouco [...] Fiquei assim porque vim do interior. Não conhecia ninguém nessa terra, foi difícil me virar. Mas logo acerto tudo" (MARCOS, 2003, p. 74); contudo, ao se instalar na cidade grande, Tonho se envolveu em uma vida marginal, devido às suas dificuldades financeiras. Tomando como base essa sua estada na cidade, logo se percebe que seu perfil se relaciona ao do pícaro, pois

[a] cidade é o espaço das relações humanas adequadas e até necessárias para o picaresco. Fora da cidade, o pícaro desaparece [...]. Ele é um modo de existência numa cidade grande e populosa, preferentemente uma capital, que permita o comportamento irregular ao facilitar o anonimato, os deslocamentos e o encontro de vítimas. Não é a cidade a origem do pícaro, porém ela é seu centro de atração, pois nela encurtam-se as distâncias sociais (GONZÁLEZ, 1994, p. 74).

Os grandes centros urbanos são próprios para as ações fraudulentas da personagem picaresca e de Tonho: ao vir para a cidade, passa a cometer delitos e tem seu caráter transformado. A condição de desempregado e a falta de perspectivas o levam a atitudes extremas, tais como roubo e assassinato, o que permite nova relação entre Tonho e o pícaro, já que este, como afirma González (1994, p. 54), “[...] não seria um aventureiro, mas um homem que, devido à crise, perdeu sua estabilidade; seu objetivo seria recuperar essa estabilidade e abandonar a vida picaresca $[. .$.$] ". Assim como acontece ao$ pícaro, Tonho se desestabiliza socialmente; porém, antes de se envolver em seus crimes, ele tenta de todas as maneiras sair de forma honesta da situação de miséria, prova disso, cita-se, como exemplo, a ideia de vender seu revólver, a fim de obter algum dinheiro e se incorporar ao meio social. Tal como o pícaro, "[...] infringe as normas de convivência social, mas, ao mesmo tempo, procura meios de entrar na sociedade [...]" (GEREMEK, 1995, p. 214).

Por outro lado, as constantes humilhações que sofre, principalmente as de Paco, fazem com que Tonho se sinta inconformado com sua vida. No decorrer da peça, esta personagem lamenta a falta de uma ocupação que considere digna para si: “[...] Sou inteligente, podia ter uma chance. Não precisava viver nessa bosta como um vagabundo qualquer. Tenho que aturar até desaforo" (MARCOS, 2003, p. 94), e observa-se sua revolta por se enxergar como sujeito que não se enquadraria naquela situação de miséria, nem suportar as dificuldades financeiras enfrentadas em seu cotidiano.

No que se refere à relação entre Tonho e Paco, pode-se dizer que ela é marcada por uma série de desentendimentos, de confrontos de pontos de vista, em acontecimentos, muitas vezes, banais. Essas personagens, assim como "[...] os viventes de Plínio Marcos, estão sempre agredindo e expondo[-se] a agressões e violências, numa permanente destruição" (BLISKSTEIN, 1978, p. 122). Prova maior disso é o assalto que ambos planejam, o qual não rende bons resultados a eles devido ao modo como um quer se aproveitar do outro na partilha dos objetos roubados. Percebe-se que nessa relação, Tonho e Paco tentam apoiar-se um ao outro, mas isso não ocorre. Exemplificando:
TONHO - Você podia me ajudar.
PACO - Ninguém me ajuda. Por que vou te ajudar?
TONHO - É só você me emprestar seu sapato. Eu arranjo emprego, depois, se eu puder fazer alguma coisa por você, eu faço.
PACO - Eu, te emprestar meu sapato? Não tenho filho do seu tamanho.
TONHO - É só um dia.
PACO - Sai pra lá. Se vira de outro jeito (MARCOS, 2003, p. 82).

O individualismo de Paco o faz negar qualquer ajuda ao companheiro de quarto, e atos como esse seu são um dos motivos que, aos poucos, levam essas personagens ao aniquilamento físico e moral: Paco morre e Tonho se torna assassino; condições estas resultantes da incapacidade de um conhecer o caráter e a formação sociocultural do outro, como nesta fala de Tonho, carregada de juízo de valor sobre Paco: "Eu sou muito mais esperto e trabalho muito mais que você" (MARCOS, 2003, p. 70). Nessa autoafirmação, Tonho se enxerga superior ao companheiro, devido à sua formação intelectual, portanto com maiores chances de arrumar um bom emprego e obter melhores condições financeiras.

Aliado a essa competitividade entre ambos, o modo violento de os dois agirem é resultado de um mundo em 
que muitos buscam apenas a realização de suas próprias vontades, por meio de atos ilícitos e sem a preocupação com o outro. Essas duas personagens, assim como grande parte dos seres ficcionais plinianos, são capazes das maiores atrocidades, rivalizando com outros indivíduos para conquistar o que tanto desejam.

A ideia de assaltar os namorados do parque, por exemplo, revela o espírito articulador de Tonho, pois seu plano, além de ter sido muito bem arquitetado antes, imediatamente envolve Paco, como ilustra esta outra cena:

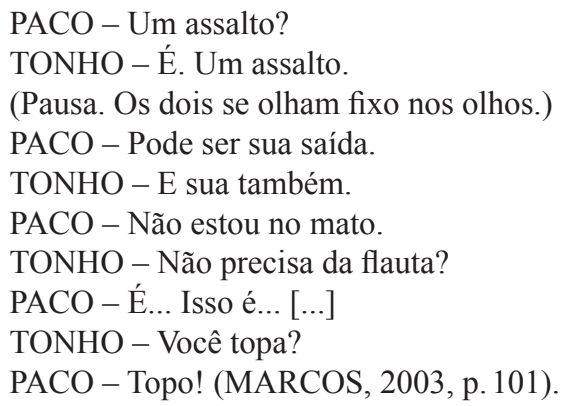

O fato de planejar o assalto faz com que Tonho demonstre seu estado desesperador por obter dinheiro. Quanto ao envolvimento de Paco, pode-se dizer que Tonho, na relação com aquele, observou que seu companheiro de quarto, propenso a uma vida de crimes, aceitaria de qualquer forma ajudá-lo naquela empreitada.

Realizado seu plano, a princípio Tonho arrepende-se desse ato criminoso e reconhece que foi levado por sua desesperadora situação: "Eu estudei, Paco. Só tive aquela infeliz ideia do assalto porque precisava [...]. Eu quero ser como todo mundo, ter um emprego de gente, trabalhar" (MARCOS, 2003, p. 126). Ele, assim, aspira a um modelo não marginalizado de vida, em que conviva socialmente, tenha um emprego e viva no seio de sua família. De acordo com Dalcastagnè (2008, p. 86), esses valores perseguidos pela personagem "[...] estão de acordo com os princípios da classe média", sendo estes, assim como sua autoafirmação de boa escolaridade, possíveis marcas indicadoras da superioridade de Tonho perante os demais marginalizados; contudo, seus crimes dissolvem todo o seu caráter.

Outra agravante que colabora para que Tonho assuma um comportamento irado é a má distribuição dos objetos roubados. Após discutir com Paco, Tonho aceita, dentre os itens do roubo, ficar apenas com o par de sapatos roubado, uma vez que sua pretensão era obter calçados novos. Porém, ao calçar seus sapatos, percebe que os mesmos não lhe servem, porque são menores que seus pés. Tal situação serve para que Paco acentue seu deboche:

\author{
PACO - Pensa que vai embora? \\ TONHO - Penso, não. Vou. \\ PACO - Você não pode ir [...] \\ TONHO - E por que não? \\ PACO - Porque nós temos que ficar juntos. (MARCOS, \\ 2003, p. 122).
}

A constatação feita por Paco de que pertencem àquele mundo marginal, conotando a ideia de uma cumplicidade criminosa entre ambos, provoca mais desespero em Tonho, que passa a enxergar o outro como responsável por arrastá-lo à miséria financeira e humana, assim mata Paco, contrariando o que dizia sobre si mesmo, conforme Marcos (2003, p. 79): “[...] não estou a fim de matar ninguém". No entanto, ao tomar essa atitude extrema, Tonho assume de vez a condição marginal de que tanto desejava se livrar, já que o assassinato é uma contravenção que contraria os princípios morais da sociedade, a qual pune com a exclusão aqueles que desobedecem às normas sociais.

Conseguindo livrar-se definitivamente de Paco, Tonho toma os sapatos que pertenciam àquele e busca a chance de sair daquela realidade de extrema miséria. Antes, porém, é a principal vítima das agressões do companheiro de quarto e visto como covarde na óptica deste: "Quem mandou você afinar? Agora é dureza fazer a moçada pensar que você é de alguma coisa. Seu apelido lá no mercado agora é 'Boneca do Negrão'" (MARCOS, 2003, p. 85). Quando se vê derrotado, seja pela dureza da vida, seja pela tensa relação com seu companheiro, assume o papel de dominador e expõe toda a sua frieza, quando ameaça Paco: "Vou acabar com você. [...] Prefere um tiro nos cornos ou um beliscão? Só que o beliscão vai ser no saco com o alicate. E, enquanto eu aperto, você vai ter que tocar gaita" (MARCOS, 2003, p. 133). O espírito zombador, antes incorporado por Paco, agora faz parte do caráter perverso de Tonho, que de oprimido transformase em opressor daquele que pode ser considerado seu inimigo.

Curiosamente, o significado do apelido Tonho no Dicionário de nomes próprios (2014), pode ser relacionado a essa mudança de caráter da personagem. Tonho é uma forma diminutiva do nome Antonio, tendo este o seguinte significado: "Mesmo com origem obscura, é possível que o nome Antônio tenha surgido do latim Antonius, que significa 'valioso, inestimável, digno de apreço"” (SIGNIFICADO, 2014, s.p.). De certa forma, o significado de Antonio pode se referir à identidade que Tonho assume durante a trama, quando se engrandece dos predicados que possui, enxergando-se como um ser cujos atributos morais e profissionais superam os de Paco. Porém, acaba revelando uma imagem que contradiz isso, e, de Antonio (nome social) passa a Tonho (nome 
marginalizado), alcunha esta que supõe a minimização de suas qualidades.

Em relação à outra personagem, Paco, as primeiras características observadas nele demonstram que ele é um sujeito analfabeto, pretensioso e que sempre humilha seu companheiro de quarto. A maioria das falas e ações de Paco é carregada de desprezo e, até mesmo, repulsa por todos que possam impedir a realização de suas vontades. Diz ter vivido em um asilo, nunca se refere às suas origens e almeja ser gaitista.

Mas, quando aprender gaita, adeus, mercado. Dou pinote. Me largo na vida de novo. Não quero outra coisa. Só ali no come-e-dorme. Pelos bares, enchendo a caveira de cachaça, às custas dos trouxas. Você precisa ver, seu. Arrumava cada jogada! Sentava na mesa dos bacanas. Bebia, bebia, bebia, tocava um pouquinho só e metia o olho na coxa da mulherada. Era de lascar. Poxa, vida legal eu levava (MARCOS, 2003, p. 91-92).

Por essa fala, percebe-se a importância que Paco dá a uma vida boêmia, sem se preocupar com família, trabalho formal ou outras tarefas vitais ao ser humano, o que demonstra seu comportamento de indivíduo livre das convenções sociais. Relacionado a isso, no Dicionário de nomes próprios (2014), o apelido Paco é um diminutivo de origem espanhola do nome Francisco, que: "Tem origem no latim Franciscus, que veio do germânico Frank, que quer dizer 'franco' [...]. Franco significa 'livre' [...]" (SIGNIFICADO, 2014, s.p.). Nesse sentido, pode-se dizer que o significado do nome Francisco tem a ver com as atitudes de Paco, já que este prioriza sua liberdade, mas, por outro lado, seu apelido, da mesma forma que a alcunha Tonho, conota sua condição marginal.

Apesar de se igualarem quanto à precariedade de vida e à vontade de sair da marginalidade em que se encontram, percebe-se, por meio de suas falas e ações, que Paco e Tonho têm comportamentos e expectativas de vida distintas: este, ao contrário daquele, deseja trabalhar honestamente, visando à carreira de funcionário público, e sempre preocupado com seus pais, como se observa a seguir:

TONHO - [...] Poxa, se eu faço uma besteira qualquer, minha mãe é que sofre. Ela já chorou paca no dia que saí de casa. [...] Mas minha cidade não tem emprego. Quem quer ser alguma coisa na vida tem que sair de lá. Foi o que fiz. [...] Vou voltar, mas só quando me aprumar na vida.

PACO - Então nunca mais vai ver sua coroa.

TONHO - E por que não?

PACO - Não força a paciência. Você nunca vai ser alguém. [...] Aqui você só vai entrar bem. (MARCOS, 2003, p. 80-81, grifo meu).
Em sua relação com o outro, Paco tenta eliminar por meio de sua visão de mundo ruim as expectativas de Tonho (exemplificado no grifo da citação acima), por isso, como tentativa de resolução das dificuldades que enfrentam, tenta induzir o companheiro a cometer atos violentos, sugerindo-lhe, por exemplo, que pratique um assalto: "Você tem um berro"1, os outros têm sapato. [...] Tem a faca e o queijo na mão e não sabe cortar. Poxa, já vi muito cara louco, mas você é o rei. Quero que se dane!" (MARCOS, 2003, p.96). Nessa fala, Paco demonstra um ponto de vista seu: a violência como a única saída para os problemas das duas personagens; ideia negada a princípio por Tonho, mas logo este acata as provocações do outro, porque se conscientiza de sua precária situação: em outra aproximação com o pícaro, deve-se mencionar que a visão de mundo deste aparece como elemento essencial no romance picaresco. Seu olhar sobre o que o cerca surge como uma "[...] espécie de aprendizagem, que amadurece e faz o protagonista recapitular a vida à luz de uma filosofia desencantada" (CANDIDO, 2004, p. 20). Assim, o pícaro assume um "comportamento próprio", e sua realidade choca-se com a da sociedade, provocando-lhe, assim como em Tonho, a conscientização de sua marginalidade.

Nesse contexto de hostilidades, as atitudes de Tonho estão voltadas para a agressão física, como resposta às agressões verbais de Paco. Este, por sua vez, utiliza-se do deboche para atingir agressivamente seu companheiro. Nota-se que o tom debochado está aliado ao sentimento de superioridade de Paco, o que reflete o desejo dele em se impor sobre o outro.

A brutalidade também se relaciona às zombarias da personagem, uma vez que as humilhações e os xingamentos proferidos por esta ferem profundamente a moral de Tonho. Esse menosprezo pelo outro, arraigado no caráter de Paco e manifestado pelo deboche deste, remete à seguinte observação de González (1994, p. 7374): "O pícaro parte, assim, para a agressão, que frequentemente assume a forma de vingança. [...] Uma forma de agressão na picaresca é a burla, que deriva no riso, mas num riso desumano e insolidario [...]". Semelhante ao pícaro espanhol, como descrito por González (1994), Paco agride porque tenta se vingar de todos aqueles que o marginalizam e, no choque com aquela realidade cruel, não conhece a solidariedade nem pratica atos afetuosos.

Na relação de Paco e Tonho, como dito anteriormente, percebe-se que a ausência de qualquer traço fraterno agrava a rivalidade entre os dois, principalmente por parte de Paco, que defende sua forma de agir da seguinte maneira: "Não dou arreglo. Mesmo que possa, não dou

\footnotetext{
1 Revólver.
} 
bandeja pra sacana nenhum. Nunca ninguém me deu nada. [...] Você acha que alguém dá alguma coisa de graça pra alguém?" (MARCOS, 2003, p.99). As palavras do ex-flautista apontam para a sua condição marginalizada, quando diz não receber auxílio de ninguém, e demonstram sua visão negativa de mundo, segundo a qual é impossível uma relação tranquila entre indivíduos, sendo cada um por si. A partir desse seu ponto de vista, Paco intensifica sua agressividade verbal contra aquele com quem se relaciona no decorrer da peça:

\footnotetext{
PACO - Você é um trouxa.

TONHO - Você não tem nada que ver com a minha vida.

PACO - Afinou como uma bicha. Poxa, que papelão!

TONHO - Papelão, não. Bati um papo com o negrão, ficou tudo certo.

PACO - Você é que acha.

TONHO - O negrão está legal comigo. Até tomamos umas pinguinhas juntos.

PACO - Muito bonito pra sua cara. O sujeito te cafetina, você ainda paga bebida pra ele. Você é um otário. [...]

TONHO - [...] Foi pra evitar briga. Eu estudei, não preciso me meter em encrenca (MARCOS, 2003, p. 83-84).
}

Maculando a imagem do outro, Paco também revela como ele enxerga o companheiro de quarto. De acordo com Candido e Prado (2009), o embate provocado pela visão que Paco tem de Tonho e vice-versa vai delineando novas características dos dois. Como se vê, o primeiro julga a personalidade de Tonho, insultando-o com termos pejorativos, como "trouxa", "bicha" e "otário", uma vez que se mostra inconformado com o fato de o companheiro ter resolvido pacificamente seu problema com Negrão, dizendo-se contrário àquele modo de agir: "[...] se um cara começa a dizer pra todo mundo que eu sou fresco e os cambaus, eu ferro o miserável. Comigo é assim. Pode ser quem for; folgou, dou pau [...]" (MARCOS, 2003, p. 78). Assumindo-se como "machão", Paco acredita que tal condição possibilite sua superioridade diante o outro no mundo degradado em que vive, por isso humilha e despreza aqueles que ele julga os mais fracos. Como justifica Vieira (1994), no universo machista enfocado por Plínio Marcos, a exposição da força bruta e a agressão à honra do outro são os dois elementos que caracterizam os "machos dominantes", para se ajustarem ao meio social.

Outro ponto divergente entre Paco e Tonho é a imagem que têm de Negrão, figura que motiva os anseios e as ações dos dois carregadores. Enquanto Tonho enxerga tal sujeito como mau elemento, Paco considera esse mesmo indivíduo de outra forma:
PACO - [...] Poxa, aquele negrão é cheio de chaveco. [Ele] dá uma sorte bárbara. Sempre tem um cara dando moleza pra ele. Arrumou você pra cafetinar... e hoje o filho da puta me levou no bico. Dei toda a ficha do assalto pro desgraçado e ele não me deixou ir junto. Vai levar aquela besta do Carocinho, um miserável que não é de coisa nenhuma. [...] Disse que eu sou muito porra-louca. [Aquele] Carocinho vai entrar bem comigo. Não tinha nada que botar o nariz nessa jogada.

TONHO - Você é metido a malandro, mas todo mundo te leva (MARCOS, 2003, p. 107).

Nesse momento da trama, percebe-se que, mesmo sendo enganado, Paco nutre uma espécie de idolatria por Negrão, como se este fosse um modelo de contravenção a ser seguido. Isso porque, na visão de Paco, Negrão é o exemplo ideal de homem, o típico machão violento e sem escrúpulos, que utiliza a agressividade para exercer o poder sobre o outro.

Nesse sentido, Lima (1999, p. 17) explica que “[...] é da violência que se vale o homem para manter o poder ou o que talvez julgue ser o seu direito de domínio"; tal afirmação justifica a admiração de Paco pela perspicácia e valentia de Negrão, pois, vivendo na miséria e dela não conseguindo se livrar, Paco encontra na imposição de poder a garantia de se sentir moralmente acima do outro e amenizar seus problemas.

Embora seu caráter seja visto por Tonho como o de pessoa presunçosa e ingênua, a visão que Paco tem de si mesmo é percebida quando planeja o assalto com seu companheiro de quarto. Empolgado com o plano, Paco passa a se considerar uma "celebridade" criminosa, vislumbrando, na sua ingenuidade, um futuro promissor na bandidagem: "Eu sou Paco. Cara estrepado. Ruim como a peste [...] Minha fuça vai sair em tudo que é jornal. Todos vão se apavorar de saber que Paco, o Perigoso, anda solto por aí [...] Se folgar, leva ferro" (MARCOS, 2003, p. 116). Essa autoafirmação mostra que Paco, almejando ter seu retrato nos jornais, deseja seu reconhecimento social, mesmo que de forma negativa.

Nos momentos decisivos da peça, após praticarem o assalto, os dois carregadores passam à partilha dos bens roubados:

PACO - Metade da grana pra cada um. Relógio, isqueiro, caneta e carteira, pra mim. Pulseira, anel, broche e cinta pra você. Topa?

TONHO - O brinco pra você, o sapato pra mim.

PACO - Não! Um brinco pra você, outro pra mim. Um pé de sapato pra você, outro pra mim [...]

TONHO - Não seja burro. O que é que vou fazer com um pé de sapato? [...] O sapato é meu. Eu já falei mais de mil vezes. Eu só entrei nesse assalto por causa dele e vou ficar com ele (MARCOS, 2003, p. 121). 
Movido pela ambição e pelo egoísmo, Paco exige sua parte no roubo, o que faz aumentar a rivalidade com Tonho. Finalmente, após aceitar todos os objetos roubados, em troca do par de sapatos, Paco humilha ainda mais Tonho: "Olha, pega os brincos pra você. [...] Quando for sair de brinco, avisa. Quero ver a bichona toda enfeitada. Vou morrer de rir" (MARCOS, 2003, p. 122). Como visto antes, diante dessas afrontas e totalmente sem expectativas, Tonho revela gradativamente sua personalidade violenta. Destarte, pode-se dizer que sua identidade se forma a partir da relação conflitante com o outro.

Na visão de Tonho, Paco é um obstáculo que impede a realização de seus anseios, e isso o desestrutura moral e socialmente. Nesse momento, há, portanto, uma inversão de comportamento das duas personagens: Paco comportase, durante toda a trama, como um delinquente, capaz das maiores atrocidades com os demais indivíduos, como demonstra esta sua fala sobre a abordagem às vítimas do assalto: "Se eles espernearem, dou uma paulada na cabeça do desgraçado. [...] Dou uma na cuca do cara e fim. Calam o bico na hora" (MARCOS, 2003, p. 110). Porém, Paco fica à mercê da esperteza de Tonho, temendo-o e suplicando-lhe para que poupe sua vida, como atesta esta sua fala desesperada, quase no desfecho do enredo: "Poxa, Tonho, não faz isso comigo. Poxa, Tonho! Pelo amor de Deus! Não faz isso comigo!" (MARCOS, 2003, p. 133). Nesse sentido, passa da condição de agressor à de agredido, por ser enganado, humilhado e, por fim, friamente executado.

Essa inversão de identidade (agressor/agredido) de Tonho e Paco revela que ambos vivem aterrorizados, respectivamente, pela marginalização e pela morte. "O terror, por sua natureza, ataca a individualização [...], ele desumaniza. Há uma perda da identidade individual" (GOLOMB, 2008, p. 188). Desse modo, as duas personagens sentem o terror de se perderem socialmente e nada têm (nem material nem moralmente), conhecem apenas a violência como resposta a seus problemas e necessidades.

\section{Referências}

BLISKSTEIN, Isidoro. Plínio Marcos: o discurso da violência. Contexto, revista quadrimestral, São Paulo, n. 5, p. 117-142, mar. 1978.

CANDIDO, Antonio. O discurso e a cidade. In: CANDIDO, Antonio. O discurso e a cidade. 3. ed. Rio de Janeiro: Ouro Sobre Azul, 2004. p. 15-129.

CANDIDO, Antonio; PRADO, Décio de Almeida et al. A personagem de ficção. 11. ed. São Paulo: Perspectiva, 2009.

CEIA, Carlos. E-dicionário de termos literários. [s.1.], 2010. Disponível em: <http://www.edtl.com.pt/index.php? option $=$ com_content $\&$ view $=$ frontpage \&Itemid $=1>$. Acesso em: 02 jun. 2012.
DALCASTAGNÈ, Regina. Vozes na sombra: representação e legitimidade na narrativa contemporânea. In: DALCASTAGNÈ, Regina. Ver e imaginar o outro. Vinhedo: Horizonte, 2008. p. 78-107.

ENEDINO, Wagner Corsino; SOUSA, Celeste da Silva. Subalternidade, marginalidade e violência num tempo sem lei: uma leitura de Querô, uma reportagem maldita e híbrida. Revista estação literária, Londrina, v. 12, p. 370-387, jan. 2014. Disponível em: <http:/www.uel.br/pos/letras/EL/vagao/EL12Art24.pdf>. Acesso em: 01 fev. 2014.

FREIRE, Rafael de Luna. Navalha na tela: Plínio Marcos e o cinema brasileiro. Rio de Janeiro: Leia Brasilis, 2008.

GEREMEK, Bronislaw. Os filhos de Caim: vagabundos e miseráveis na literatura europeia (1400-1700). São Paulo: Companhia das Letras, 1995.

GOLOMB, Abigail. Terror na infância. In: VARVIN, Sverre; VOLKAN, Vamik Djemal. Violência ou diálogo?: reflexões psicanalíticas sobre terror e terrorismo. São Paulo: Perspectiva, 2008. p. 187-197.

GONZÁLEZ, Mario Miguel. A saga do anti-herói: estudo sobre o romance picaresco espanhol e algumas de suas correspondências na literatura brasileira. São Paulo: Nova Alexandria, 1994.

LIMA, Luiz Ferreira. Violência e poder. São Paulo: Iglu, 1999.

MARCOS, Plínio. Dois perdidos numa noite suja. In: MARCOS, Plínio. O melhor teatro de Plínio Marcos. São Paulo: Global, 2003. p. 61-134.

MARTIN, Vima Lia. Literatura e marginalidade: um estudo sobre João Antônio e Luandino Vieira. São Paulo: Alameda, 2008 .

MENDES, Oswaldo. Bendito maldito: uma biografia de Plínio Marcos. São Paulo: Leya Brasil, 2009.

MOISÉS, Massaud. A criação literária: poesia e prosa. São Paulo: Cultrix, 2012.

MOISÉS, Massaud. Diálogo. In: MOISÉS, Massaud. Dicionário de termos literários. São Paulo: Cultrix, 1974. p. 143-148.

PARANHOS, Kátia Rodrigues. A literatura dramática de Plínio Marcos: cenas da(s) cidade(s). Periódico do programa de pósgraduação em artes cênicas PPGAC/UNIRIO, Rio de Janeiro, n. 01, p. 1-11, jan./jun. 2009. Disponível em: $<$ http://seer.unirio. br/index.php/opercevejoonline> . Acesso em: 06 ago. 2011.

PAVIS, Patrice. Dicionário de teatro. 3.ed. São Paulo: Perspectiva, 2011.

PEACOCK, Ronald. Formas da literatura dramática. Rio de Janeiro: Zahar, 1968.

RYNGAERT, Jean-Pierre. Introdução à análise do teatro. 1. ed. São Paulo: Martins Fontes, 1996.

SIGNIFICADO dos nomes. Dicionário de nomes próprios. [s.1.], 2014. Disponível em: <http://www.dicionariodenomesproprios. com.br>. Acesso em: 12 jul. 2014.

VIEIRA, Paulo. Plínio Marcos: a flor e o mal. Rio de Janeiro: Firmo, 1994.

Recebido: $17 / 12 / 16$

Aprovado: 25/03/17

Contato: tenorames@gmail.com 